RESEARCH ARTICLE

\title{
Evaluation of 18 isolates of basidiomycetes for Lignocellulose degrading enzymes
}

\author{
M. Kathirgamanathan ${ }^{1}$, C.L. Abayasekara ${ }^{2}$, S.A. Kulasooriya ${ }^{1}$, A. Wanigasekera ${ }^{3}$, R.R. \\ Ratnayake ${ }^{1, *}$
}

${ }^{1}$ National Institute of Fundamental Studies, Hantana Road, Kandy, Sri Lanka
${ }^{2}$ Department of Botany, University of Peradeniya, Peradeniya, Sri Lanka
${ }^{3}$ Faculty of Veterinary Medicine, University of Peradeniya, Peradeniya, Sri Lanka

Received: 04/07/2017; Accepted: 11/09/2017

\begin{abstract}
Since fossil fuel resources are limited there is a necessity to produce alternative types of fuel that are renewable and eco-friendly. Basidiomycetes are potential sources of enzymes that can be used for biofuel production. The current study aimed to isolate basidiomycetes from Sri Lanka, screen them for lignocellulose degrading enzymes, namely cellulase, xylanase, laccase, Mn peroxidase and lignin peroxidase and study the effect of potential inducers of laccase production. Among the eighteen basidiomycetes isolated, Pycnoporus sp. produced the highest cellulase activity $(0.23 \mathrm{FPU} / \mathrm{ml})$ whereas Phlebiopsis sp. produced the highest xylanase activity (5.4 U/ml). Earliella scabrosa produced the highest laccase $(91.2 \mathrm{U} / \mathrm{l})$ and $\mathrm{Mn}$ peroxidase (17.5 U/l) activities. Lignin peroxidase activity was not detected from the isolates. Effect of alkali lignin, $\mathrm{Cu}^{2+}$ and rice bran, three potential inducers, on laccase production by E. scabrosa, Pycnoporus sp. and Trametes hirsuta (M40) was studied. Results indicated that alkali lignin $(2 \mathrm{~g} / \mathrm{l})$ significantly increased laccase production from Pycnoporus sp. and $T$. hirsuta (M40) while $\mathrm{Cu}^{2+}$ increased laccase production from E. scabrosa and $T$. hirsuta at $200 \mu \mathrm{M}$. Use of rice bran $(10 \mathrm{~g} / \mathrm{l})$ resulted in higher laccase production from E. scabrosa and Pycnoporus sp. High laccase activity (79600 U/l) was obtained from E. scabrosa by using $50 \mathrm{~g} / \mathrm{l}$ of rice bran and by extending the incubation period to 18 days. The study concluded that some of the basidiomycetes isolated can produce significant lignocellulose degrading enzyme activities.
\end{abstract}

Keywords: Basidiomycetes, Cellulase, Xylanase, Laccase, Mn peroxidase.

\section{INTRODUCTION}

Fossil fuel resources are limited and their utilization leads to global warming and other environmental problems. Hence, it is necessary to produce alternative types of fuel that are renewable and eco-friendly. Biofuel production from plant cell wall polysaccharides is an attractive alternative to fossil fuel. It involves saccharification of the polysaccharides and fermentation of the resultant sugars to the desired biofuel. Due to lignification of plant cell walls, treatment with enzymes alone results in slow and incomplete saccharification (Zhang et al., 2007). Hence, currently the plant materials are subjected to thermo-chemical pre-treatment prior to enzymatic hydrolysis (Margeot et al., 2009). The costs of pre-treatment and saccharifying enzymes add to the overall cost of production, thereby negatively affecting its economic viability. Biological pre-treatment with lignin degrading enzymes is a potential alternative that may be carried out under milder conditions at lower cost.

The enzymes mainly required for the saccharification of plant polysaccharides are cellulases and xylanases (Bischof et al., 2016). Lignin degrading enzymes include laccase, manganese peroxidase (MnP) and lignin peroxidase (LiP) (Pollegioni et al., 2015). While laccase requires oxygen for its activity, $\mathrm{MnP}$ and LiP require hydrogen peroxide. Auxiliary enzymes such as aryl alcohol oxidase and glyoxal oxidase produce the hydrogen peroxide required for their activity (Daou et al., 2016). Since many basidiomycetes are known to degrade both cellulose and lignin efficiently (Zhu et al., 2016), they may be used as sources of enzymes for both biological pre-treatment and saccharification.

Degradation products of lignin act as the natural inducers of laccase (Janshekar et al., 1981). $\mathrm{Cu}^{2+}$ is an integral component of laccase and induces laccase production in many fungal species (Piscitelli et al., 2011). Rice bran contains $0.9-2.9 \%$ of $\gamma$-oryzanols, which are predominantly esters of trans-ferulic acid with 
phytosterols (Lerma-Garcia et al., 2009). Ferulic acid also induces laccase in certain basidiomycetes (Piscitelli et al., 2011).

The objective of the current study was to isolate basidiomycetes from the Central Province of Sri Lanka and screen them for the production of lignocellulose degrading enzymes, namely cellulase, xylanase, laccase, Mn peroxidase and lignin peroxidase, under submerged culture conditions. Further, effect of three potential inducers, namely alkali lignin, $\mathrm{Cu}^{2+}$ and rice bran, on laccase production by three selected basidiomycetes was investigated. It was hypothesized that the potential inducers may significantly increase laccase production by the selected isolates.

\section{MATERIALS AND METHODS}

\section{Reagents and Instrumentation}

Alkali lignin, $\mathrm{CuSO}_{4} .5 \mathrm{H}_{2} \mathrm{O}$ and the salts used for media preparation were from Sigma (USA). Potato dextrose agar and yeast extract were from HiMedia (India). ITS1 and ITS4 oligonucleotide primers were from Integrated DNA Technologies Inc. Mytaq ${ }^{\mathrm{TM}}$ DNA polymerase and Mytaq ${ }^{\mathrm{TM}}$ reaction buffer $(5 \mathrm{x})$ used for the polymerase chain reaction were from Bioline (Australia). UV-Vis spectrophotometry was carried out by using Shimadzu UV-2450 UV-Vis spectrophotometer.

\section{Isolation and preservation of basidiomycetes}

Fruiting bodies of basidiomycetes were collected from the Central Province of Sri Lanka $\left(5^{\circ} 54^{\prime} \mathrm{N}\right.$ - $9^{\circ} 52^{\prime} \mathrm{N}$ latitude and $79^{\circ} 39^{\prime} \mathrm{E}-81^{\circ} 53^{\prime} \mathrm{E}$ longitude). A piece of tissue was removed from the stipe of the basidiocarp and surface-sterilized with $70 \%$ ethanol for one minute followed by $3 \%$ $\mathrm{H}_{2} \mathrm{O}_{2}$ for 30 seconds. The tissue was subsequently washed with sterile distilled water and placed on potato dextrose yeast extract agar (PDYA) with gentamicin $(50 \mathrm{mg} / \mathrm{l})$, chloramphenicol $(50 \mathrm{mg} / \mathrm{l})$ and carbendazim (1 $\mathrm{mg} / \mathrm{l})$. The basidiomycetes were further purified by successive plate transfers, maintained on PDYA slopes at $2-8{ }^{\circ} \mathrm{C}$ and preserved in sterile distilled water in airtight screw capped tubes at room temperature (de Capriles et al., 1989).

\section{Identification of the basidiomycetes}

The basidiomycetes were identified based on morphological characteristics and/or DNA sequencing of the ITS region. Genomic DNA was extracted from the basidiomycetes according to Cenis (1992), with an additional step of freezing and thawing prior to homogenization of the cells. PCR amplification was performed with ITS1 and ITS4 primers (White et al., 1990). The PCR products were sequenced at Macrogen Inc. (South Korea). Consensus sequences were made from the forward and reverse sequences and were analysed for similarity with existing nucleotide sequences in the NCBI and ENA databases by using the BLAST tool.

\section{Enzyme production for screening}

Cellulase and xylanase activities were evaluated in a medium modified from Peláez et al. (1995). It contained (per litre): cellulose, $10 \mathrm{~g}$; glycerol, $0.5 \mathrm{~g} ; \mathrm{KNa}$ tartrate tetrahydrate, $3 \mathrm{~g}$; $\left(\mathrm{NH}_{4}\right)_{2} \mathrm{HPO}_{4}, 1 \mathrm{~g}$; yeast extract, $1 \mathrm{~g} ; \mathrm{KCl}, 0.5 \mathrm{~g}$; $\mathrm{MgSO}_{4} \cdot 7 \mathrm{H}_{2} \mathrm{O}, \quad 0.5 \mathrm{~g} ; \mathrm{CaCl}_{2} \cdot 2 \mathrm{H}_{2} \mathrm{O}, 0.3 \mathrm{~g}$; $\mathrm{FeSO}_{4} .7 \mathrm{H}_{2} \mathrm{O}, 5 \mathrm{mg}$; trace element solution, $1 \mathrm{ml}$. Trace element solution contained [per $100 \mathrm{ml}$ ]: $\mathrm{ZnSO}_{4} .7 \mathrm{H}_{2} \mathrm{O}, 100 \mathrm{mg} ; \mathrm{CuSO}_{4} .5 \mathrm{H}_{2} \mathrm{O}, 25 \mathrm{mg}$; $\mathrm{MnSO}_{4} \cdot \mathrm{H}_{2} \mathrm{O}, 100 \mathrm{mg} ; \mathrm{CoCl}_{2} \cdot 6 \mathrm{H}_{2} \mathrm{O}, 100 \mathrm{mg}$; $\left(\mathrm{NH}_{4}\right)_{6} \mathrm{Mo}_{7} \mathrm{O}_{24} \cdot 4 \mathrm{H}_{2} \mathrm{O}, 10 \mathrm{mg} ; \mathrm{Na}_{2} \mathrm{~B}_{4} \mathrm{O}_{7} \cdot 10 \mathrm{H}_{2} \mathrm{O}$, $10 \mathrm{mg} . \mathrm{pH}$ of the medium was adjusted to 5.6. Laccase, MnP and LiP activities were evaluated in a medium modified from the afore-mentioned medium by replacing cellulose and glycerol with glucose $(10 \mathrm{~g} / \mathrm{l})$. The basidiomycetes were grown on PDYA and circular discs of growth (diameter $=5 \mathrm{~mm}$ ) were cut from near the edge of each colony by using a sterile cork borer. Each disc was radially cut into 8 equal pieces with a sterile scalpel, in order to reduce the pellet size of growth under submerged condition. Growth from three discs from each basidiomycete was inoculated to $20 \mathrm{ml}$ of the medium in $100 \mathrm{ml}$ Erlenmeyer flasks and incubated at $28{ }^{\circ} \mathrm{C}$ in the dark with shaking at $100 \mathrm{rpm}$. After 7 days, the cultures were filtered with Whatman No.1 filter paper and the filtrates were used for the enzyme assays.

\section{Enzyme assays}

Total cellulase assay was performed with Whatman No.1 filter paper as the substrate (Mandels et al., 1976). Reducing sugars formed were measured by using 3,5-dinitro salicylic acid (DNS) reagent (Miller, 1959) with glucose standards. The total cellulase activity was 
expressed as filter paper units per $\mathrm{ml}(\mathrm{FPU} / \mathrm{ml})$ which is the amount of reducing sugar, in micromoles, released by $1 \mathrm{ml}$ of undiluted enzyme per minute. Xylanase activity was measured according to Gottschalk et al. (2010) with beechwood xylan (Sigma) as the substrate and the reducing sugars formed were measured by using DNS reagent with xylose standards. Laccase activity was measured by using ABTS (2,2'-azino-bis-3-ethylbenzothiazoline-6-

sulphonate) as the substrate (Bourbonnais et al., 1995). The assay mixture $(3 \mathrm{ml})$ contained 0.5 $\mathrm{mM}$ ABTS, $100 \mathrm{mM}$ sodium acetate (pH 5.0) and $300 \mu 1$ of culture supernatant. The oxidation of ABTS was followed by measuring the absorbance at $420 \mathrm{~nm}$ at one second intervals for 60 seconds at room temperature. The absorbance readings were plotted against time as shown in Figure 1. If the absorbance readings became nonlinear within 60 seconds, then the culture supernatant was diluted in distilled water to obtain tenfold dilutions and the diluted supernatant was used for the assay. The enzyme activity of undiluted supernatant was calculated by multiplying the activity of the diluted supernatant by the dilution factor. The amount of oxidized product formed was calculated by using the Beer-Lambert equation $A=\varepsilon c l$, where $A=$ absorbance, $\varepsilon=$ molar absorptivity, $c=$ concentration of the analyte and $l=$ path length of the cuvette. Molar absorptivity of $36 \mathrm{mM}^{-1} \mathrm{~cm}^{-1}$ (Bourbonnais et al. 1995) was used for the calculations. Manganese peroxidase (MnP) activity was measured by using phenol red as the substrate (Peláez et al., 1995). The reaction mixture $\left(3 \mathrm{ml}\right.$ ) contained $0.1 \mathrm{mM} \mathrm{H}_{2} \mathrm{O}_{2}, 0.1 \mathrm{mM}$ $\mathrm{MnSO}_{4}, 0.1 \mathrm{mg} / \mathrm{ml}$ phenol red, $100 \mathrm{mM}$ sodium tartrate buffer ( $\mathrm{pH} 5.0$ ) and $1 \mathrm{ml}$ of crude enzyme. Reaction was stopped by the addition of $120 \mu \mathrm{l}$ of $2 \mathrm{M} \mathrm{NaOH}$ after 30 minutes. The increase in absorption at $610 \mathrm{~nm}$ was measured against the corresponding enzyme blank (to which $120 \mu \mathrm{l}$ of $2 \mathrm{M} \mathrm{NaOH}$ was added prior to the addition of the reaction mixture). The amount of phenol red oxidized was calculated by using the Beer-Lambert equation and the molar absorptivity $\varepsilon 610=4460 \mathrm{M}^{-1} \mathrm{~cm}^{-1}$ (Peláez et al., 1995). Lignin peroxidase activity was measured by using methylene blue as the substrate (Magalhães et al., 1996). The assay mixture (3 $\mathrm{ml}$ ) contained $0.1 \mathrm{ml}$ of $1.2 \mathrm{mM}$ methylene blue, $0.6 \mathrm{ml}$ of $0.5 \mathrm{M}$ sodium tartrate $(\mathrm{pH} 4.0)$ and 2.2 $\mathrm{ml}$ of enzyme. Reaction was started by the addition of $0.1 \mathrm{ml}$ of $2.7 \mathrm{mM} \mathrm{H} \mathrm{H}_{2}$. Conversion of the dye to Azure $\mathrm{C}$ was determined by measuring the absorbance at $664 \mathrm{~nm}$ immediately after the addition of $\mathrm{H}_{2} \mathrm{O}_{2}$ and again after 30 minutes. Enzyme activity was expressed as the decrease in absorbance at $664 \mathrm{~nm}$ per minute.

\section{Effect of potential inducers on laccase production}

To determine the effect of alkali lignin and $\mathrm{Cu}^{2+}$ on laccase production, alkali lignin (0.5 g/l, $2 \mathrm{~g} / \mathrm{l})$ or $\mathrm{CuSO}_{4} .5 \mathrm{H}_{2} \mathrm{O}(50 \mu \mathrm{M}, 200 \mu \mathrm{M})$ were included in the medium. To determine the effect of rice bran on laccase production, glucose in the medium was reduced to $1 \mathrm{~g} / \mathrm{l}$ and finely ground and sieved $(80 \mu \mathrm{m})$ rice bran was included at 10 $\mathrm{g} / \mathrm{l}$. Glucose was included in the medium at $1 \mathrm{~g} / \mathrm{l}$ in order to shorten the possible lag phase in the growth of the isolates.

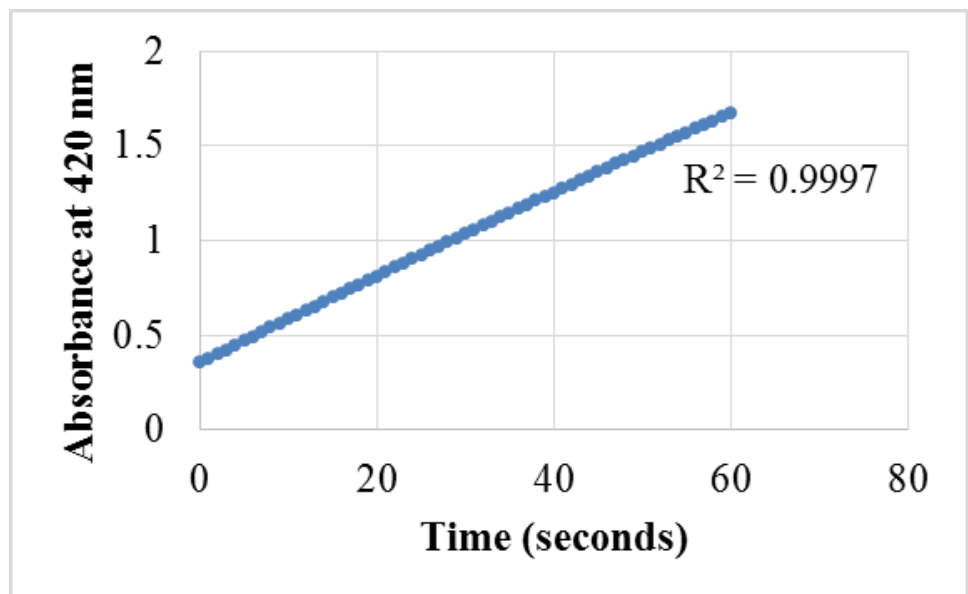

Figure 1: A plot of absorbance at $420 \mathrm{~nm}$ against time during oxidation of ABTS by laccase present in a culture supernatant. 


\section{Statistical analysis}

Statistical analyses were carried out by using Minitab $^{\circledR} 17$ statistical software. Comparisons were made by ANOVA with Tukey's method or by two sample t-test $(\alpha=0.05)$. Culturing of basidiomycetes and enzymatic degradations were carried out in triplicates.

\section{RESULTS AND DISCUSSION}

\section{Isolation, identification and screening of enzyme activities of the basidiomycetes}

In total, 18 basidiomycetes were isolated (Figure 2 ). Their identities and the enzyme activities when grown in the screening media are shown in Table 1. Cellulase activity was detected from 16 out of the 18 basidiomycetes, while xylanase activity was detected in all. Pycnoporus sp. produced the highest cellulase activity of 0.23 FPU/ml, which is comparable to the activities produced by the wild type filamentous fungus Trichoderma reesei QM6a (Mandels, 1975), which is the parent strain of the mutant strain Trichoderma reesei RUT-C30, used for industrial production of cellulases (Peterson and and Nevalainen, 2012). The highest xylanase activity of $5.4 \mathrm{U} / \mathrm{ml}$ was produced by Phlebiopsis sp. Other isolates that produced high xylanase activities included Schizophyllum commune (M1) (5.12 U/ml) and Pycnoporus sp. (4.59 U/ml).

Laccase activities greater than $10 \mathrm{U} / 1$ were produced by Earliella scabrosa, Polyporus sp. (M20), Pycnoporus sp., Trametes hirsuta (M29), T. hirsuta (M36) and T. hirsuta (M40).
Mn peroxidase $(\mathrm{MnP})$ activities greater than 10 U/1 were produced by Coprinopsis sp., $E$. scabrosa and T. hirsuta (M40). The highest laccase (91.2 U/1) and MnP activities (17.5 U/1) were both produced by E. scabrosa. LiP activity was not detected from any of the isolates. In a similar study, Peláez et al. (1995) also found no LiP activity within a larger collection of basidiomycetes. Thus, it appears LiP activity is rare among the basidiomycetes and limited to a few species such as Phanerochaete chrysosporium (Janusz et al., 2013).

\section{Effect of alkali lignin, $\mathrm{Cu}^{2+}$ and rice bran on laccase production}

The effect of alkali lignin, $\mathrm{Cu}^{2+}$ and rice bran on laccase production by three selected basidiomycetes (E. scabrosa, Pycnoporus sp. and T. hirsuta (M40)) was studied. The three basidiomycetes were selected based on their high laccase and MnP activities during the initial screening (Table 1).

Alkali lignin significantly increased laccase production by Pycnoporus sp. and $T$. hirsuta (M40) at $2 \mathrm{~g} / \mathrm{l}$ but not at $0.5 \mathrm{~g} / \mathrm{l}$ (Figure $3)$. It had no significant effect on laccase production by E. scabrosa. Pycnoporus sp. appeared to degrade alkali lignin in culture, as indicated by the reduction in brown colour of the medium. However, it could not be verified by spectrophotometry according to Janshekar et al. (1981) due to interference by pigments, proteins and other compounds secreted by the fungus.

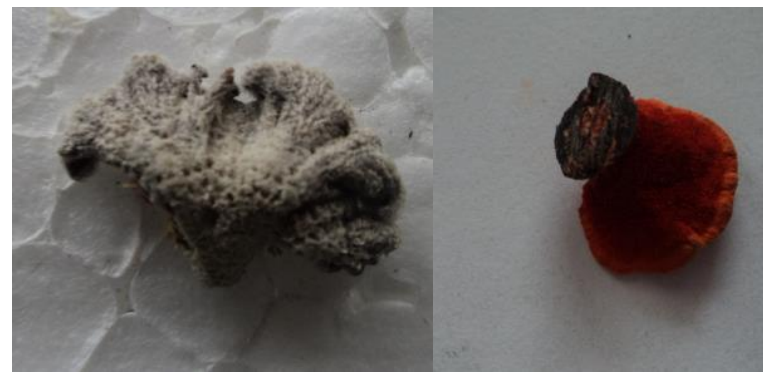

(a) (b)

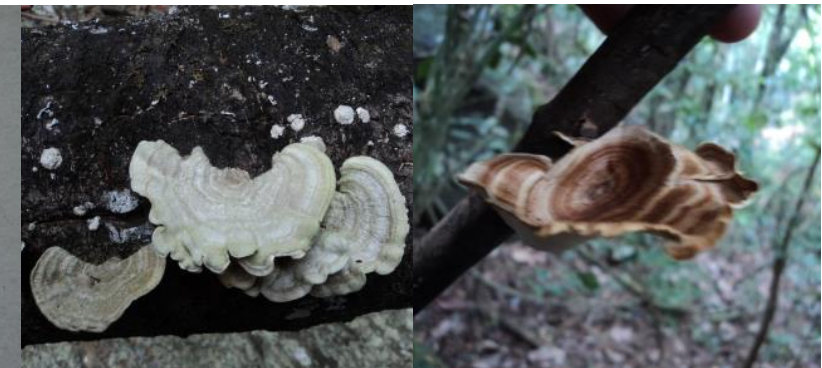

(c) (d)

Figure 2: Some of the isolated basidiomycetes (not to scale). (a) Schizophyllum commune (M1) ( 1/2 x), (b) Pycnoporus sp. (M21) $(\sim 1 / 4$ x) (c) Trametes hirsuta $($ M29) $(\sim 1 / 10$ x), (d) Microporus xanthopus (M25) $(\sim 1 / 10$ x). 


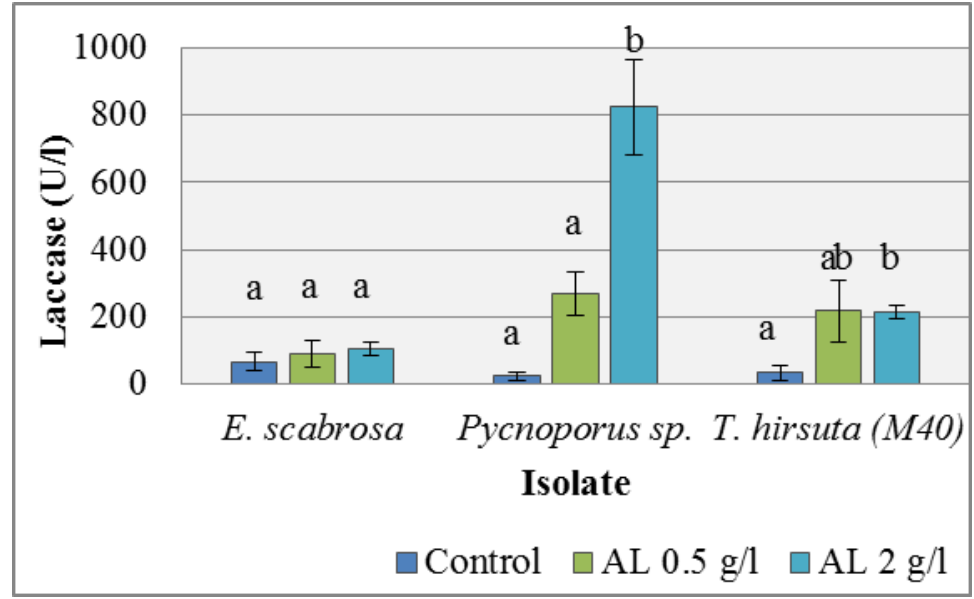

Figure 3: Production of laccase by the three selected basidiomycetes with different concentrations of alkali lignin. AL Alkali lignin. Error bars indicate standard errors of the means of triplicates. For individual isolates, values not sharing the same letter are significantly different.

Table 1: Identities and enzyme activities of the basidiomycetes collected and grown in vitro.

\begin{tabular}{|c|c|c|c|c|}
\hline Basidiomycete & $\begin{array}{l}\text { Cellulase } \\
(\text { FPU/ml) } \\
\end{array}$ & $\begin{array}{c}\text { Xylanase } \\
(\mathrm{U} / \mathrm{ml})\end{array}$ & $\begin{array}{c}\text { Laccase } \\
(\mathrm{U} / \mathrm{l})\end{array}$ & $\begin{array}{l}\text { MnP } \\
\text { (U/l) } \\
\end{array}$ \\
\hline Schizophyllum commune $^{*}(\mathrm{M} 1)^{\mathrm{a}}$ & 0.025 & 5.12 & 0.6 & 0 \\
\hline Schizophyllum commune* $(\mathrm{M} 3)^{\mathrm{a}}$ & 0.016 & 0.88 & 0.4 & 0 \\
\hline Coprinopsis sp.* (M5) & 0 & 0.08 & 2.7 & 10.45 \\
\hline Phlebiopsis sp.*(M7) & 0.074 & 5.41 & 0 & 0 \\
\hline Marasmius sp. (M12) & 0.054 & 0.70 & 0.8 & 0.29 \\
\hline Earliella scabrosa* (M14) & 0 & 0.16 & 91.2 & 17.5 \\
\hline Trametes sp. (M15) & 0.082 & 0.97 & 0.5 & 0 \\
\hline Unidentified (M17) & 0.020 & 2.50 & 0.5 & 0 \\
\hline Polyporus sp. (M20) & 0.024 & 0.30 & 79.9 & 0.91 \\
\hline Pycnoporus sp.* (M21) & 0.232 & 4.59 & 33.1 & 0.64 \\
\hline Microporus xanthopus (M25) & 0.073 & 2.60 & 0 & 0 \\
\hline 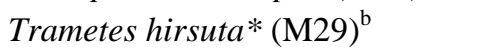 & 0.082 & 0.93 & 60.4 & 0.58 \\
\hline Annulohypoxylon stygium* (M31) & 0.033 & 3.80 & 0.5 & 0 \\
\hline Schizophyllum commune* $(\mathrm{M} 33)^{\mathrm{a}}$ & 0.029 & 1.60 & 0 & 0.08 \\
\hline 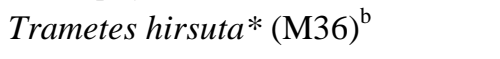 & 0.074 & 1.67 & 15.1 & 0 \\
\hline Lentinus sp.*(M37) & 0.018 & 0.10 & 0.6 & 0.16 \\
\hline Polyporus sp. (M39) & 0.018 & 0.16 & 0.2 & 0.19 \\
\hline Trametes hirsuta* $(\mathrm{M} 40)^{\mathrm{b}}$ & 0.059 & 1.24 & 69.3 & 14.87 \\
\hline
\end{tabular}

* Identifications made with the aid of the DNA sequence of ITS region. Scientific names are followed by laboratory codes shown within brackets. a, b - Isolated from different locations (Knuckles, Gannoruwa and Pilimathalawa and hence presumed to be different strains of the same species.

Presence of $\mathrm{Cu}^{2+}$ in the medium resulted in significantly higher laccase production by $E$. scabrosa and T. hirsuta at $200 \mu \mathrm{M}$, but not at 50 $\mu \mathrm{M}$ (Figure 4). No effect of $\mathrm{Cu}^{2+}$ was observed on Pycnoporus sp. $\mathrm{Cu}^{2+}$ is known to inhibit fungal growth at higher concentrations.
Laccase production by $E$. scabrosa and Pycnoporus sp. was significantly higher when rice bran $(10 \mathrm{~g} / \mathrm{l})$ was used as the main source of carbon (Figure 5). The increase was profound with E. scabrosa, which produced a mean laccase activity of $13060 \mathrm{U}^{-1}$ after 7 days of cultivation. In order to determine whether higher 
concentration of rice bran would lead to higher laccase production by E. scabrosa, the fungus was grown in the medium with $50 \mathrm{~g} / \mathrm{l}$ rice bran and $1 \mathrm{~g} / \mathrm{l}$ of glucose. After 7 days, a mean laccase activity of $4 \mathrm{U} / 1$ was obtained from the culture. However, the mean laccase activity increased to $79600 \mathrm{U} / \mathrm{l}$ after 18 days of culturing. Laccase biosynthesis is often regulated by nutrient carbon and nitrogen levels (Piscitelli et al., 2011). Hence, the delay in laccase production by $E$. scabrosa with $50 \mathrm{~g} / \mathrm{l}$ rice bran may possibly be due to higher initial carbon and nitrogen levels.

During the study, it was observed that higher pellet sizes of the fungi in submerged cultures were associated with lower laccase production. It was probably due to reduced oxygen transfer to the interior of the larger pellets. Reports on parameters affecting laccase production by other basidiomycetes support this notion (Tinoco-Valencia et al., 2014). Hence, laccase production by E. scabrosa with rice bran may be further enhanced by optimizing the pellet size, aeration and other parameters of submerged cultivation, such as rotations per minute and incubation temperature.

In addition to biofuel production, cellulase and laccase have other industrial applications such as bio-stone washing of denim and clarification of fruit juices.

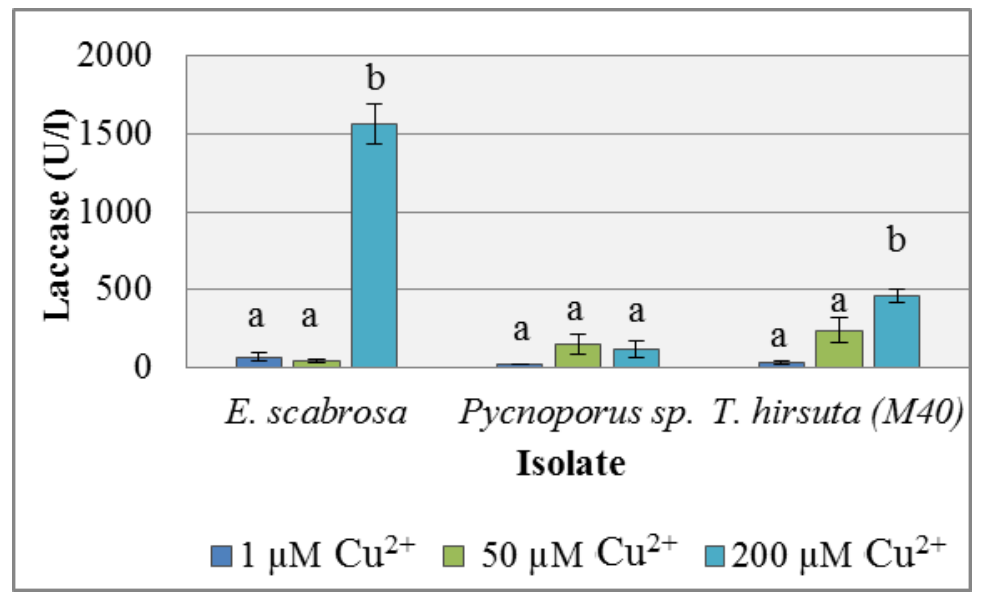

Figure 4: Production of laccase by the three selected basidiomycetes with different concentrations of $\mathrm{Cu}^{2+}$. Error bars indicate standard errors of the means of triplicates. For individual isolates, values not sharing the same letter are significantly different.

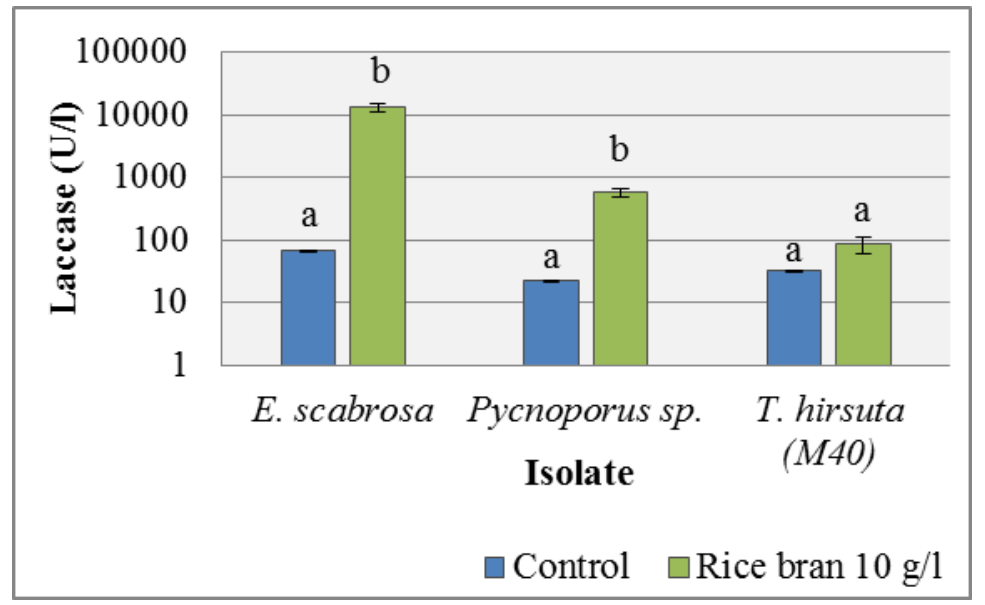

Figure 5: Production of laccase by the three selected basidiomycetes with and without rice bran. Note that the y axis is on a logarithmic scale. Error bars indicate standard errors of the means of triplicates. For individual isolates, values not sharing the same letter are significantly different. 


\section{CONCLUSIONS}

Most of the basidiomycetes that were isolated produced cellulase and xylanase activities while several of them produced laccase and MnP activities (Table 1). Pycnoporus sp. produced the highest cellulase activity along with high xylanase activity. It also produced laccase and $\mathrm{MnP}$ activities and degraded alkali lignin in culture. Thus, Pycnoporus sp. may potentially be used as a single source of enzymes for saccharification as well as delignification. Alkali lignin significantly increases laccase production by Pycnoporus sp. and T. hirsuta (M40) at $2 \mathrm{~g} / \mathrm{l}$ whereas $\mathrm{Cu}^{2+}$ causes significantly higher laccase production from E. scabrosa and T. hirsuta at $200 \mu \mathrm{M}$. Rice bran $(10 \mathrm{~g} / \mathrm{l})$ causes higher laccase production from E. scabrosa and Pycnoporus sp. Whether these effects are due to induction needs further study by quantification of the mRNAs coding for the laccases. E. scabrosa produced very high laccase activity (79600 U/l) when cultured in $50 \mathrm{~g} / \mathrm{l}$ rice bran. Thus, it can potentially be used for industrial production of laccase. Rice bran could be used as a cheap carbon source for high laccase production from E. scabrosa.

\section{ACKNOWLEDGMENT}

The authors thank Ms. R.K.C. Karunaratne, Mr. A. Pathirana, Mr. C.B. Alahakoon, Ms. P. Madamarandawala and Mr. V. Gunarathne for their assistance in sample collection, preparation and analysis. We gratefully acknowledge the financial support from National Research Council, Sri Lanka (Grant no 12-031).

\section{REFERENCES}

Bischof, R.H., Ramoni, J. and Seiboth, B. (2016). Cellulases and beyond: the first 70 years of the enzyme producer. Trichoderma reesei. Microbial cell factories 15: 1-13.

Bourbonnais, R., Paice, M.G., Reid, I.D., Lanthier, P., and Yaguchi, M. (1995). Lignin oxidation by laccase isozymes from Trametes versicolor and role of the mediator 2,2'-azinobis(3ethylbenzthiazoline-6-sulfonate) in kraft lignin depolymerization. Applied and Environmental Microbiology 61: 1876-1880.

Cenis, J.L. (1992). Rapid extraction of fungal DNA for PCR amplification. Nucleic Acids Research 20: 2380.

Daou, M., Piumi, F., Cullen, D., Record, E. and Faulds, C.B. (2016). Heterologous production and characterization of two glyoxal oxidases from Pycnoporus cinnabarinus. Applied and Environmental Microbiology 82: 4867-4875.

de Capriles, C.H., Mata, S. and Middelveen, M. (1989). Preservation of fungi in water (Castellani): 20 years. Mycopathologia 106: 7379.

Gottschalk, L.M.F, Oliveira, R.A. and Bon, E.P.S. (2010). Cellulases, xylanases, $\beta$-glucosidase and ferulic acid esterase produced by Trichoderma and Aspergillus act synergistically in the hydrolysis of sugarcane bagasse. Biochemical Engineering Journal 51: 72-78.

Janshekar, H., Brown, C. and Fiechter, A. (1981). Determination of biodegraded lignin by ultraviolet spectrophotometry. Analytica Chimica Acta 130: 81-91.

Janusz, G., Kucharzyk, K.H., Pawlik, A., Staszczak, M. and Paszczynski, A.J. (2013). Fungal laccase, manganese peroxidase and lignin peroxidase: gene expression and regulation. Enzyme and Microbial technology 52: 1-12.

Lerma-Garcia, M.J., Herrero-Martinez, J.M., SimóAlfonso, E.F., Mendonça, C.R. and RamisRamos, G. (2009). Composition, industrial processing and applications of rice bran $\gamma$ oryzanol. Food Chemistry 115: 389-404.

Magalhães, D.B., Carvalho, M.E.A., Bon, E., Neto, J.S.A. and Kling, S.H. (1996). Colorimetric assay for lignin peroxidase activity determination using methylene blue as substrate. Biotechnology Techniques 10: 273-276.

Mandels, M. (1975). Microbial sources of cellulase. Biotechnology and Bioengineering Symposium 5 : 81-105.

Mandels, M., Andreotti, R. and Roche, C. (1976). Measurement of saccharifying cellulase. Biotechnology and Bioengineering Symposium 6: 21-33.

Margeot, A., Hahn-Hagerdal, B., Edlund, M. Slade, R. and Monot, F. (2009). New improvements for lignocellulosic ethanol. Current Opinion in Biotechnology 20: 372-380.

Miller, G.L. (1959). Use of Dinitrosalicylic acid reagent for determination of reducing sugar. Analytical Chemistry 31: 426-428.

Peláez, F., Martínez, M.J. andMartínez, A.T. (1995). Screening of 68 species of basidiomycetes for enzymes involved in lignin degradation. Mycology Research 99: 37-42.

Peterson, R. and Nevalainen, H. (2012). Trichoderma reesei RUT-C30-thirty years of strain improvement. Microbiology 158: 58-68.

Piscitelli, A., Giardina, P., Lettera, V., Pezzella, C., Sannia, G. and Faraco, V. (2011). Induction and transcriptional regulation of laccases in fungi. Current Genomics 12: 104-112.

Pollegioni, L., Tonin, F. and Rosini, E. (2015). Lignin-degrading enzymes. The FEBS journal 282: 1190-1213. 
Tinoco-Valencia, R., Gómez-Cruz, C., Galindo, E. and Serrano-Carreón, L. (2014). Toward an understanding of the effects of agitation and aeration on growth and laccases production by Pleurotus ostreatus. Journal of Biotechnology 177: 67-73.

White, T.J., Bruns, T., Lee, S.J.W.T. and Taylor, J.W. (1990). Amplification and direct sequencing of fungal ribosomal RNA genes for phylogenetics. In Innis, M.A., Gelfand, D.H., Sninsky, J.J. and White, T.J. (Eds.) PCR protocols: a guide to methods and applications, Academic Press, New York. Pp. 315-322.
Zhang, Y.H.P., Ding, S.Y., Mielenz, J.R., Cui, J.B., Elander, R.T., Laser, M., Himmel, M.E., McMillan, J.R. and Lynd, L.R. (2007) Fractionating recalcitrant lignocellulose at modest reaction conditions. Biotechnology and Bioengineering 97:214-223.

Zhu, N., Liu, J., Yang, J., Lin, Y., Yang, Y., Ji, L. and Yuan, H. (2016). Comparative analysis of the secretomes of Schizophyllum commune and other wood-decay basidiomycetes during solid-state fermentation reveals its unique lignocellulosedegrading enzyme system. Biotechnology for biofuels 9: 1-22. 